\title{
Bridges over the troubled Conservation of Iberian Bats
}

\author{
Francisco Amorim $^{1,5 *}$, Pedro Alves ${ }^{2,3}$ Hugo Rebelo ${ }^{1,4}$ \\ ${ }^{1}$ InBIO/CIBIO, Centro de Investigação em Biodiversidade e Recursos Genéticos, \\ Campus Agrário de Vairão, R. Padre Armando Quintas, 4485-661 Vairão (Portugal) \\ ${ }^{2}$ Plecotus - Estudos Ambientais Unipessoal, Lda. Rua de Ansião, nº 1, $1^{\circ}$ dto 3100-474 Pombal, (Portugal) \\ ${ }^{3}$ Escola de Ciências e Tecnologia, Universidade de Évora, Largo dos Colegiais 2, 7004-516 Évora, (Portugal) \\ ${ }^{4}$ School of Biological Sciences, University of Bristol, Woodland Road, Bristol BS8 1UG, (UK) \\ * Corresponding author e-mail: famorim@cibio.up.pt
}

DOI: http://dx.doi.org/10.14709/BarbJ.6.1.2013.01

Spanish title: Puentes en la problemática conservación de los murciélagos Ibéricos

\begin{abstract}
In the last decades the availability of roosts has been one of the major limiting factors in bat conservation. Several human-made structures mimic the conditions occurring in natural roosts allowing the maintenance of bat populations and in some cases, even their range expansion. In the USA and Europe several bridges have been reported to be used by bats as roosts. We surveyed 52 bridges in Northeastern Portugal and found that 28 bridges were used by bats from 16 species. Most species seem to use bridge crevices, but cave dwellers were also observed in box girders. At least 3145 individuals were found roosting in crevices, most of which were identified as Tadarida teniotis. A total of 728 individuals were captured in 8 different bridges. T. teniotis was the most common species since it was the target species of these captures. The observed sex bias toward females suggests that bridges are often used as breeding colonies. Signs of swarming and mating were also observed in September and October. Our results confirm that modern bridges can play an important role in bat conservation even contributing to range expansions.
\end{abstract}

\section{INTRODUCTION}

In the last decades, the availability of roosts has been one of the major limiting factors in bat conservation (Hutson et al. 2001). Optimal roosts provide shelter and reduce individual metabolic costs while supplying suitable conditions for bats' annual cycle, including the harbouring of hibernation and nursery colonies (Speakman et al. 1992; Webb et al. 1995), and also protect bats from predators (e.g. Russo et al. 2007)). Several humanmade structures mimic the conditions occurring in natural roosts (Altringham 1996). These structures allow the maintenance of bat populations and in some cases, even their range expansion (Rodrigues et al. 2003): clear examples are mines and cellars which frequently provide suitable roosting conditions for cave-dwelling species (Mitchell-
Jones et al. 2007). The loss of natural roosts due to land use change has increased importance of artificial roosts, and in some cases the latter are essential for the survival of many bat species (Bat Conservation Trust 2012).

In USA out the use of bridges by bats as day or night roosts has been reported several times (Keeley \& Tuttle 1999; Adam \& Hayes 2000; Mcdonnell 2001; Feldhamer et al. 2003; Hendricks et al. 2005; Geluso \& Mink 2009). Twenty-eight of the 47 bat species occurring in the USA are known to use bridges and culverts as day and/or night roosts (Keeley \& Tuttle 1999; Hendricks et al. 2005; Geluso \& Mink 2009), with Tadarida brasiliensis being the most abundant and the most widespread species. Twenty-five of these species are listed as 


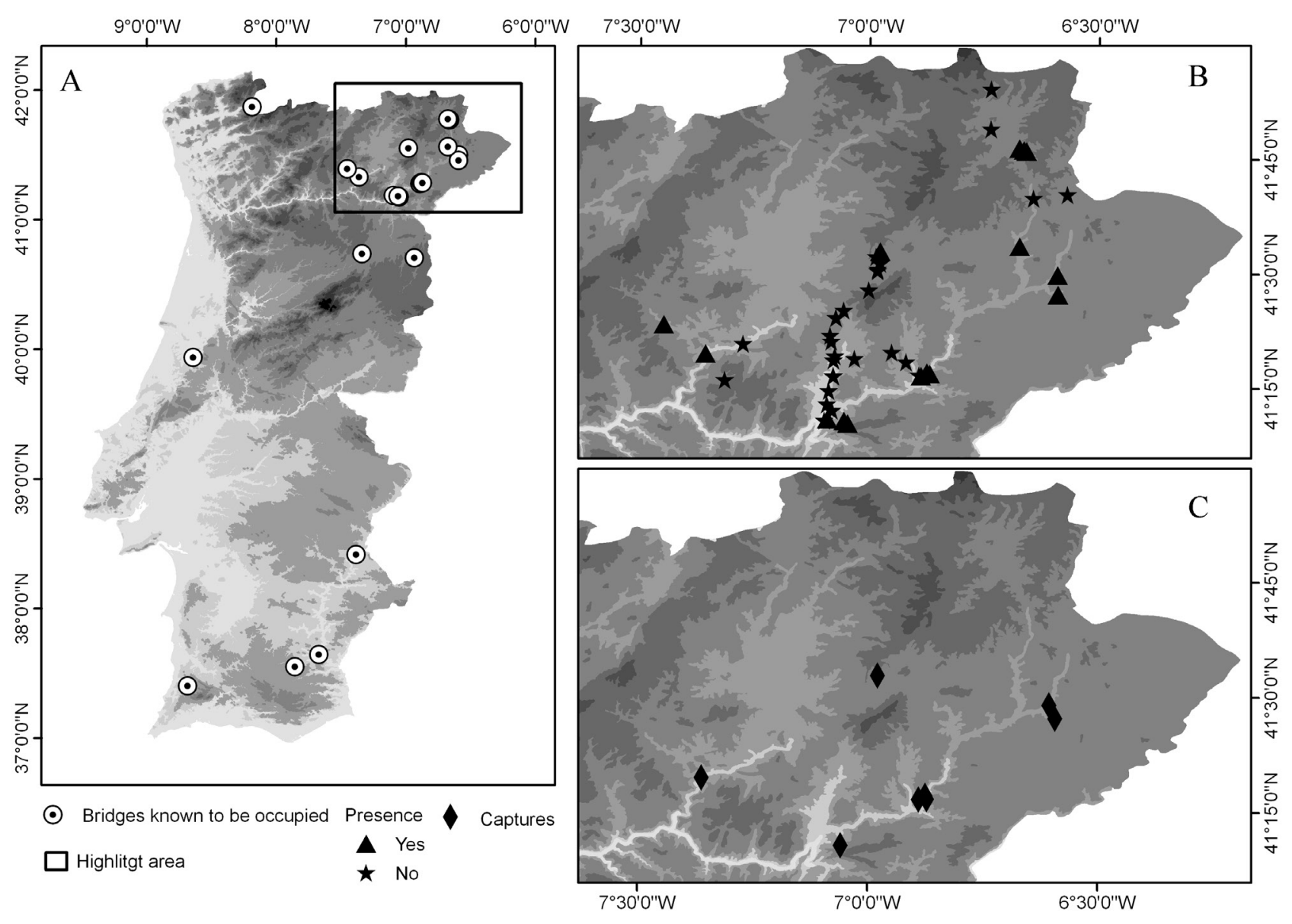

Fig. 1 - Bridges known to be occupied in mainland Portugal (A) and highlight of the study area showing bridges that are occupied and those that are not (B) and bridges where bats were captured (C).

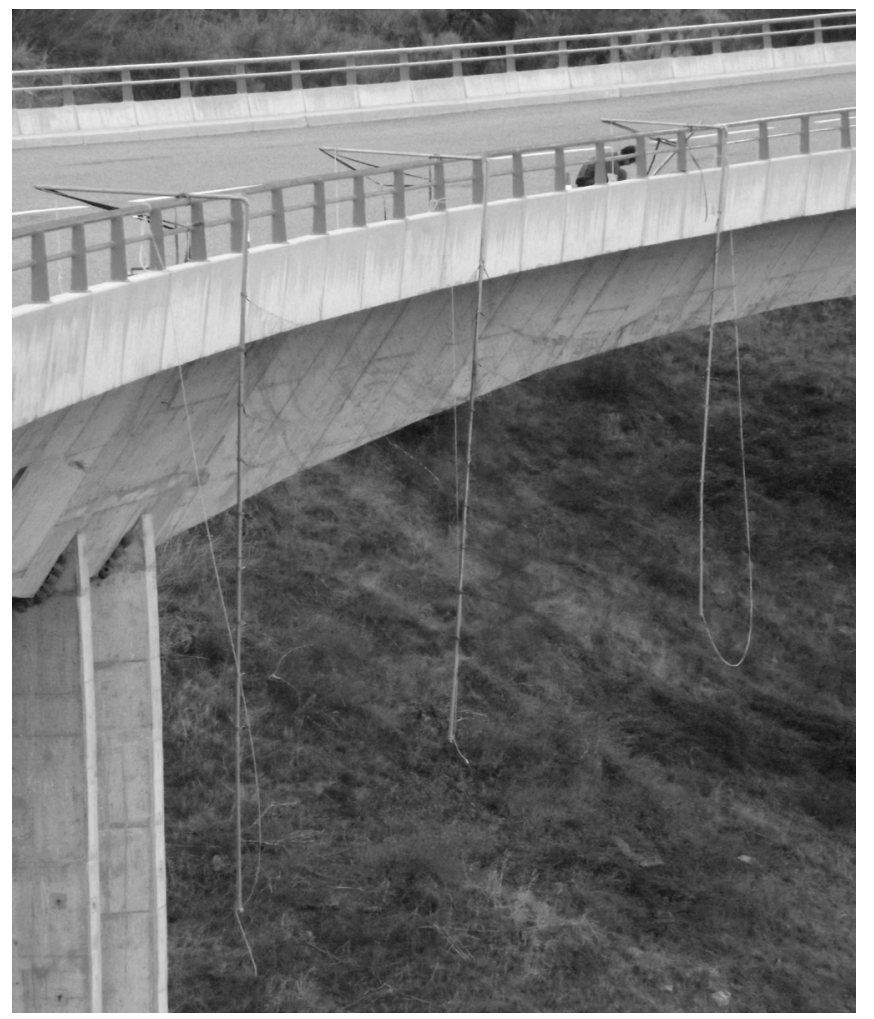

Fig. 2 - Trap specifically designed to capture bats roosting in bridges. "low concern" and three are threatened (IUCN 2012).

Guidelines for bridge maintenance taking into account the presence of bat colonies have been developed by a number of conservation agencies (Keeley \& Tuttle 1999; NCHRP 2005). These reports are an example of how bridges are carefully considered for the conservation of bats in the U.S.A.

In Europe, studies regarding the use of bridges as roosts by bats are less common and usually concerning old stone bridges (Rolandez \& Pont 1986; Shiel 1999; Keeley 2007; Masterson et al. 2008). Nonetheless, there are a few studies regarding the presence of bats in more modern bridges (Ibañez \& Pérez-Jordá 1998; Dietz 2006; Pysarczuk \& Reiter 2008; Hartman \& Herold 2010). In these studies, 32 of the 47 known European species were found roosting in bridges (Dietz et al. 2009; Marnell \& Presetnik 2010): Myotis spp. seem to be the most common, especially Daubenton's bats (Myotis daubentonii), 
Table 1 - List of species found roosting in bridges in Portugal, with the bridge part where they were found and conservation status in Portugal (Cabral et al. 2005), Spain (Palomo et al. 2007) and worldwide (IUCN 2012). (*) Species recently reclassified for which conservation status has not yet been assessed.

\begin{tabular}{lllll}
\hline Species & Part of Bridge used & $\begin{array}{l}\text { Status } \\
\text { (Portugal) }\end{array}$ & $\begin{array}{l}\text { Status } \\
\text { (Spain) }\end{array}$ & Status (IUCN) \\
\hline Rhinolophus ferrumequinum & Box girder & VU & NT & LC \\
\hline Rhinolophus hipposideros & Box girder & VU & NT & LC \\
\hline Myotis escalerai & Crevices & & & \\
\hline Myotis myotis & crevices, box girder & VU & VU & LC \\
\hline Myotis daubentonii & Crevices & LC & NA & LC \\
\hline Pipistrellus pipistrellus & Crevices & LC & - & LC \\
\hline Pipistrellus pygmaeus & Crevices & LC & - & LC \\
\hline Hypsugo savii & Crevices & DD & NT & LC \\
\hline Eptesicus serotinus & Crevices & LC & & LC \\
\hline Eptesicus isabellinus & & & & \\
\hline Nyctalus leisleri & Crevices & DD & NT & LC \\
\hline Nyctalus lasiopterus & Crevices & DD & VU & NT \\
\hline Barbastella barbastellus & Crevices & DD & NT & NT \\
\hline Plecotus auritus & Crevices & DD & NT & LC \\
\hline Plecotus austriacus & Crevices & LC & NT & LC \\
\hline Tadarida teniotis & crevices, box girder & DD & NT & LC \\
\hline
\end{tabular}

but Pipistrellus spp., Eptesicus spp. and Plecotus spp. among others, also roost in these structures.

In Europe, guidelines for the consideration of bat colonies in bridge maintenance are less common than in U.S.A.: the Eurobats Publication Series no 4 (Marnell \& Presetnik 2010) has devoted a chapter to this subject, and France, Germany and U.K. also have some guidelines (Lemaire \& Arthur 2002; Mitchell-Jones \& McLeish 2004; Dietz 2006; CREN-MP 2009; Laviolle et al. 2011). Yet, the occurrence of very large colonies is still not acknowledgeable raising the question of whether bridges could be as relevant for bat conservation in Europe as in the U.S.A.

In Portugal, the presence of bats roosting in bridges are very scarce and has been reported occasionally and never dealt with by specific surveys (Rainho et al. 1998; Bekker et al. 2004; Alves et al. 2008). However, in 2010, during an environmental assessment study of a highway in North-eastern Portugal, a large number of Tadarida teniotis was found roosting in crevices from several bridges (Reis \& Rufino 2012).

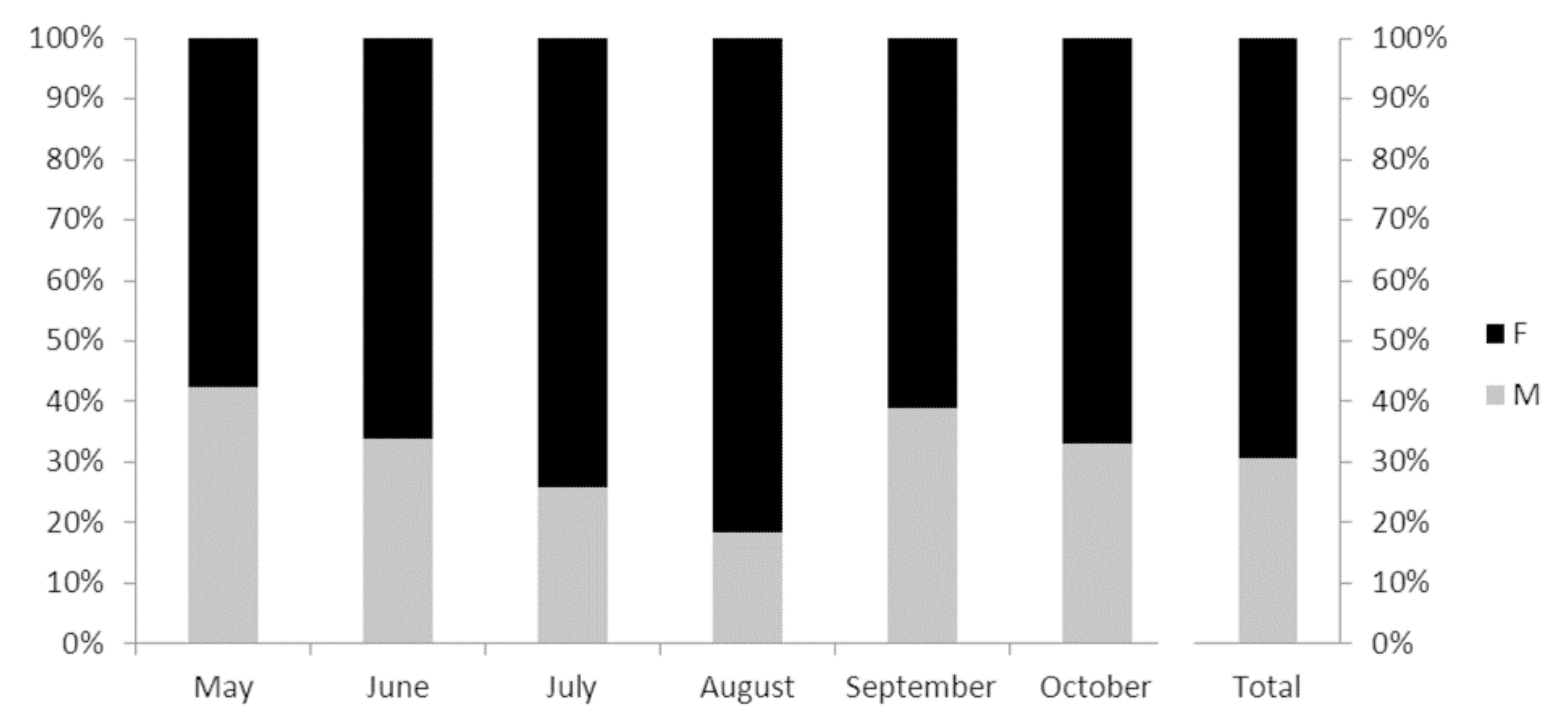

Fig. 3 - Number of individuals captured per square meter of net during the study and total. 


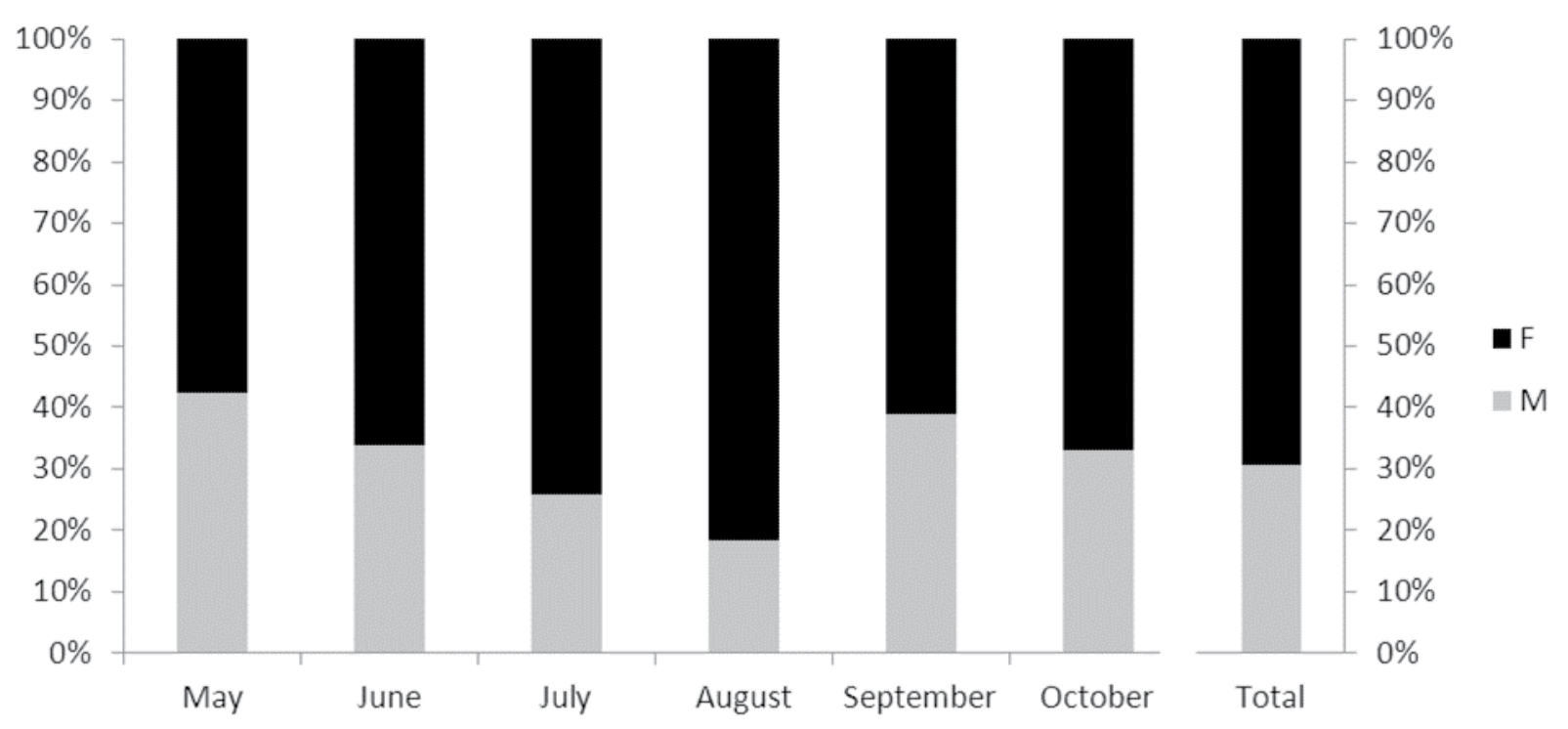

Fig. 4 - Tadarida teniotis sex ratio during the study and total ( F - Female, M - Male).

We developed two different approaches to confirm the use of bridges by bat species. On one hand, we made systematic searches for bat roosts in bridges of North-eastern Portugal, using binoculars and a videoscope. In parallel, because $T$. teniotis is a species with a large knowledge gap, we surveyed colonies in bridges from the same region, using a trap specifically designed for this purpose. In this paper, we show the first results.

\section{Materials And Methods}

The majority of the results presented in here are from a specific project running since 2012 to study bats roosting in bridges in North-eastern Portugal at coordinates $41^{\circ} 20^{\prime} \mathrm{N}$ and $7^{\circ} \mathrm{W}$ (see Highlight Area in Fig. 1) though other findings obtained in mainland Portugal are also presented.

\section{Bridge surveys}

We searched bats roosting in crevices from under the bridges using binoculars (Bushnell Powerview, $10 \times 50 \mathrm{~mm}, 6 \mathrm{~m}$ minimum focus, $114 \mathrm{~m}$ field of view) or from the top of the bridges using a videoscope (16mm 0lux camera, with $1.9 \mathrm{~m}$ total length and a 2.36" color wireless LCD, from $\mathrm{OH}$ !Haus). The searches were made at both sides of each bridge, along its full length.

Whenever possible we also surveyed box girders to search for bats or evidence of their presence (i.e. droppings).

\section{Captures}

We developed a special trap to increase the capture efficiency of bats roosting in bridge crevices. The trap consists of a steel frame that can be secured to the bridge rails or walls. This system can be easily assembled by two operators and the capturing surface is adjustable by moving vertically up to two mist-nets. Length is also adjustable and in our case up to three sections of 12 meters could be assembled (Fig. 2).

In 2012 this trap was assembled in 37 nights in a total of $4982 \mathrm{~m}^{2}$ of nets. Trapping sessions lasted since sunset till dawn.

\section{Data analysis}

For analysis purposes, we only considered results from captures, namely number of bats captured and sex composition for $T$. teniotis.

Preliminary data analysis revealed that data were neither homogeneous nor normally-distributed, even after transformation. Therefore, we used non-parametric tests specifically Kruskall-Wallis test and Chi-square test (Dytham 2011). Both for Kruskall-Wallis and Chi-squared tests the null hypothesis was rejected when $\mathrm{p}$ was less than 0.05 (Dytham 2011). Kruskall-Wallis test was used to test for differences in the number of bats captured between months, while Chi-squared test was used to check whether sex composition in T. teniotis captures was random. 
Table 2 - Bridges surveyed using binoculars and videoscope where bats were found showing species and number of individuals.

\begin{tabular}{|c|c|c|}
\hline Bridge & Species & Number individuals \\
\hline Bridge 01 & Pipistrellus spp. & Undetermined \\
\hline Bridge 02 & T. teniotis & 5 \\
\hline Bridge 03 & T. teniotis & 45 \\
\hline Bridge 04 & T. teniotis & Undetermined \\
\hline \multirow{2}{*}{ Bridge 05} & Eptesicus spp. & Undetermined \\
\hline & Pipistrellus spp. & Undetermined \\
\hline Bridge 06 & T. teniotis & 83 \\
\hline \multirow{3}{*}{ Bridge 07} & T. teniotis & 164 \\
\hline & Eptesicus spp. & 15 \\
\hline & Unidentified & 3 \\
\hline \multirow{3}{*}{ Bridge 08} & T. teniotis & 368 \\
\hline & Eptesicus spp. & 11 \\
\hline & Unidentified & 4 \\
\hline Bridge 09 & Eptesicus spp. & 2 \\
\hline Bridge 10 & T. teniotis & Undetermined \\
\hline \multirow{2}{*}{ Bridge 11} & T. teniotis & 73 \\
\hline & Unidentified & 1 \\
\hline \multirow{3}{*}{ Bridge 12} & T. teniotis & 432 \\
\hline & Pipistrellus spp. & 994 \\
\hline & Unidentified & 2 \\
\hline \multirow{3}{*}{ Bridge 13} & T. teniotis & 128 \\
\hline & Pipistrellus spp. & 550 \\
\hline & Unidentified & 2 \\
\hline Bridge 14 & Eptesicus spp. & 41 \\
\hline \multirow{2}{*}{ Bridge 15} & T. teniotis & 109 \\
\hline & Eptesicus spp. & 113 \\
\hline
\end{tabular}

\section{RESULTS}

We monitored a total of 52 bridges during 2012 in North-eastern Portugal, 28 of which were confirmed to be used by bats while 24 did not show any signs of occupation (Fig. 1). Additionally, another six bridges surveyed during other studies were reported to be used by bats (Fig. 1). Overall, 16 species were found in bridges (Table 1), mostly in bridge crevices. Some bridges also have a box girder which is mostly used by cave dwellers, since it mimics conditions occurring in underground roosts.

\section{Bridge survey}

We surveyed 29 bridges using a videoscope and 23 more with binoculars: although some of them were already known to be used by bats we could obtain a more precise estimate of the number of individuals roosting in the crevices and locate new colonies. This method allowed to detect bat presence in eight new bridges.

At least 3145 individuals were found in crevices using the videoscope, 1967 of which were identified as T. teniotis, 1544 as Pipistrellus spp. and 116 as Eptesicus spp. (Table 2).

Due to logistic constraints visiting box girders was not always possible, nonetheless in the four 
that were surveyed, bat presence was confirmed either from direct observation of individuals or by the presence of droppings. Cave-dwellers $(R$. ferrumequinum, $R$. hipposideros and $M$. myotis) were the most common species roosting in these structures.

\section{Captures}

In 2012 we captured a total of 728 individuals in eight different bridges, most of which were identified as Tadarida teniotis. Although this was the target species, Pipistrellus and Eptesicus species were also frequently captured. In September the number of individuals captured by net area was highest $\left(0.25\right.$ individuals $\left./ \mathrm{m}^{2}\right)$ whereas in the other months capture rates were similar (0.12-0.15 individuals $/ \mathrm{m}^{2}$ ) (Fig. 3). However this difference was not statistically significant $(\mathrm{H}=3.7, \mathrm{n}=36$, $\mathrm{p}$ $=0.59$ ). In September T. teniotis was captured on all nights, with a dawn peak when we observed bats entering and leaving the roost. Similarly, for the other species the majority of the individuals were captured when leaving, or returning to the roosts. However, Myotis escalerai was never captured leaving the roosts and on two occasions they were captured in groups (5-15) trying to enter the roosts late at night. Myotis myotis (16 males) was captured in four different bridges. In September we captured five Hypsugo savii ( 3 males and 2 females) in the same place.

When considering Tadarida teniotis alone, a sex bias was observed toward females, overall 433 females vs. 192 males were capture (Fig. 4) and Chi-square test confirmed that the number of captures for both sexes was not random $\left(\chi^{2}=\right.$ 55.83 , df $=1, p<0.00)$. A gradual decrease in males' was observed between May and August with the latter month corresponding to the lowest proportion of males relative to females (18\%). In October there was a considerable increase in the proportion of males (39\%; Fig. 4). Only in May the proportion of males and females was close to what would be expected if random $\left(\chi^{2}=1.23, \mathrm{df}=\right.$ $1, \mathrm{p}<0.27)$, while the values observed in August were the further away from random $\left(\chi^{2}=58.84\right.$, df $=1, \mathrm{p}<0.00)$.

\section{Discussion}

The high number of bridges used by bats as roosts we found indicates that such human- made structures can play an important role in bat conservation. Such importance is supported by the high number of species roosting in bridges some of which are classified as threatened in Portugal $(R$. ferrumequinum, $R$. hipposideros and M. myotis) and others as Data Deficient (H. savii, N. leisleri, $N$. lasiopterus, B. barbastellus, P. auritus and $T$. teniotis) (Cabral et al. 2005).

Apart from the findings within our research, scattered observations in mainland Portugal made it possible to confirm that bats seem to use bridges throughout the country. This pattern coupled with observations of bats also roosting in Spanish bridges (Ibañez \& Pérez-Jordá 1998) suggests that this behaviour is widespread in the Iberian Peninsula.

Not only have the survey methods we applied proven highly effective in detecting the presence of bats in bridges, but also to monitor bat colonies roosting in these structures and to capture individuals. Inspection under the bridges with binoculars is effective to detect the presence of bats but it is influenced by the numbers of accesses and rarely makes it possible to inspect the total length of the bridge. On the other hand, walking on top of the bridges with a videoscope to look into the crevices allowed us to determine the specific areas where bats were roosting and estimate colony size. The use of the videoscope was highly efficient to identify larger species such as $T$. teniotis and Eptesicus spp., but the performance was lower for smaller ones. The use of the trap we specifically designed to capture bats roosting in crevice bridges was also highly effective, and when used in combination with the videoscope it significantly increased the number of captures by locating the colonies prior to trapping.

Despite the high species richness observed, crevicedwelling species, particularly $T$. teniotis, seems to dominate in these human-made structures. This is not surprising because some bridges show many suitable crevices. The high number of individuals from the genus Pipistrellus found was mainly due to the presence of large colonies roosting in two bridges (Bridges 12 and 13, Table 2) near one of the main villages in the research area. Since these species are highly related to human presence (Dietz et al. 2009) bridges near town centres may tend to host larger Pipistrellus colonies.

The presence of box girders in some bridges can also present an opportunity for cave-dwelling species. 
Unfortunately, due to logistic constraints we were not able to visit all the box girders. However, presence was confirmed in the ones that were surveyed, and although the number of individuals was low, the amount of droppings found suggested that these roosts are frequently used. Although we did not find species such as Miniopterus schreibersii in the box girders their suitability for other cavedwelling species should not be disregarded, since these structures seem to mimic cave roosts. In Southern Italy, during a radiotracking study (Russo et al. 2002) a large summer colony was found in one of these structures crossed by a water conduit, including Rhinolophus euryale, Myotis capaccinii, Myotis emarginatus and Miniopterus schreibersii (D. Russo, pers. comm..).

The disproportionally higher number of $T$. Teniotis females observed in bridges suggests that these are used as breeding roosts albeit no juveniles or newborns were recorded. The gradual decrease in the proportion of males between May and August could result from the dispersal of juvenile males. In September, when males were more common, they were observed flying in and out of the roosts during all night - possibly swarming behaviour (Rivers et al. 2006; Glover \& Altringham 2008). Furthermore, in October a small number of females showed mating plugs, a common strategy used by males of different animal groups (Baer et al. 2001; Herberstein et al. 2012), including bats and other mammals (Phillips \& Inwards 1985; Keeley \& Keeley 2004; Munroe \& Koprowski 2012), which indicates that mating had already occurred. The groups of $M$. escalerai that were captured on two different occasions trying to enter the crevices late in the night, yet never leaving, suggest that this species can use bridges as night roosts. Individual M. myotis males roosting in bridges during summer seems to be common for the Mediterranean region (Dietz et al. 2009).

Besides remarking the conservation importance of bridges, our results also show that bridges can offer excellent research opportunities to collect data on species that are traditionally overlooked due to the difficulties inherent to their study, e.g. crevice-dwellers such as $T$. teniotis or $H$. savii whose ecology and behaviour are poorly known.

Under natural conditions, crevice-dwelling bats mostly occur in mountainous areas or even in sea cliffs that provide suitable roosting sites (Bat Conservation Trust 2012). Therefore, in Portugal those species are more concentrated in the north where mountains ridges and deep valleys are more common. The ability of some of those species to colonize artificial roosts and particularly bridges can allow them to expand their range to areas where they were previously absent or rare due to the scarcity of natural roosts (Marques et al. 2004).

\section{CONSERVATION IMPLICATIONS}

Nowadays, natural roosts are under constant pressure (disturbance or alteration) due to human activities: artificial roosts such as bridges might thus play an important conservation. This is particularly relevant for crevice-dwellers, for which creating artificial roosts that mimic natural ones is difficult. Roosting in such artificial structures do not seem to cause stress to bat populations, as shown for $T$. brasiliensis (Allen et al. 2011).

Our results show that some bridges are colonized while others are not: our current research is now trying to detect which features promote the use of bridges. Unveiling the environmental variables selected by the different species roosting in bridges is paramount to implement effective management policies and guidelines.

\section{ACKNOWLEDGEMENTS}

Thanks to Pedro Beja for all the support on this project; Fundação para a Ciência e Tecnologia (LTER/BIA-BEC/0004/2009); EDP - Energias de Portugal for funding; Ascendi and EP - Estradas de Portugal for dealing with all the authorizations to survey and capture bats in bridges; AES Associação dos Espeleólogos de Sintra and to all the field team, specially Helena Santos, Vanessa Mata and Luís Silva.

\section{REFERENCES}

Adam, M. D., \& Hayes, J. P. 2000. American Society of Mammalogists Use of Bridges as Night Roosts by Bats in the Oregon Coast Range. Journal of Mammalogy 81:402-407.

Allen, L. C., Turmelle, A. S., Widmaier, E. P., Hristov, N. I., McCracken, G. F. \& Kunz. T. H. 2011. Variation in Physiological Stress between Bridge- and Cave-Roosting Brazilian Free-Tailed Bats. Conservation Biology 25:374-381. Retrieved March 30, 
2011, from http://www.ncbi.nlm.nih.gov/ pubmed/21175827. DOI: https://dx.doi. org/10.1111/j.1523-1739.2010.01624.X

Altringham, J. D. 1996. Bats biology and behaviour. Page 262. Oxford University Press, Oxford, UK.

Alves, P., Barreiro, S. Silva, B. \& Geraldes., P. 2008. Parque Eólico do Douro Sul. Relatório de Caracterização de Quirópteros, Ano 2008. Plecotus, Lda.

Baer, B., Morgan, E. D. \& Schmid-Hempel, P. 2001. A nonspecific fatty acid within the bumblebee mating plug prevents females from remating. Proceedings of the National Academy of Sciences of the United States of America 98:3926-8. Retrieved December 29, 2012, from http://www.pubmedcentral.nih. gov/articlerender.fcgi? artid $=31155 \&$ tool $=\mathrm{pm}$ centrez\&rendertype $=$ abstract.

Bat Conservation Trust. 2012. Bats and Buildings. Bats and the Built Environment series. Bat Conservation Trust.

Bekker, H., Bekker, J. P., Boschamer, J., Buys, J., Hunia, A., Kosten, E., Mostert, K., Rienks, J., Verbeek, F. \& VAN Der Wal, A. 2004. Mammal survey Alvão Natural Park (Portugal). Veldwerkgroep VZZ. Arnhem, Netherlands.

Cabral, M. J., Almeida, J., Almeida, P. R., Dellinger, T., Ferrand de Almeida, N., Oliveira, M. E., Palmeirim, J. M., Queiroz, A. I., Rogado, L. \& Santos-Reis, M. 2005. Livro vermelho dos vertebrados de Portugal. Page 660, $2^{\mathrm{a}}$ edition. Instituto de Conservação da Natureza/Assírio \& Alvim, Lisboa.

CREN-MP. 2009. Des chauves-souris et des ponts. Fiche techniques $\mathrm{N}^{\circ} 8$. Groupe Chiroptères de Midi-Pyrénées. Conservatoire Regional des Espaces Naturels de Midi Pyrénées. Retrieved from http://www.cren-mp.org/ .

Dietz, C. 2006. Fledermause schutzen. Berucksichtigung des Fledermausschutzes bei der Sanierung von Natursteinbrücken und Wasserdurchlässen. Innenministeriums Baden-Württemberg.

Dietz, C., Nill, D. \& von Helversen, O. 2009. Bats of Europe and Northwest Africa. Page 400. A \& C Black Publishers, London.
Dytham, C. 2011. Choosing and Using Statistics: A Biologist's Guide. Page 2983rd Editio. Wiley-Blackwell, West Sussex, UK.

Feldhamer, G. A., Carter, T. C., Morzillo, A. T. \& Nicholson, E. H. 2003. Use of Bridges as Day Roosts by Bats in Southern Illinois. Transactions of the Illinois State Academy of Science 96.

Geluso, K., \& MinK, J. N. 2009. Use of Bridges by Bats (Mammalia: Chiroptera) in the Rio Grande Valley, New Mexico. The Southwestern Naturalist 54:421-429. DOI: http://dx.doi.org/10.1894/JKF-02.1

Glover, A. M., \& Altringham, J. D. 2008. Cave selection and use by swarming bat species. Biological Conservation 141:1493-1504. Elsevier. Retrieved November 13, 2012, from http://linkinghub.elsevier.com/retrieve/pii/ S0006320708001201.

Hartman, V., \& Herold, G. 2010. Fledermäuse in Autobahnbrücken. Untersuchung der Wiedtalbrücke (A 3). Presentation from the Fledermäuse in der Landschaftsplanung II, 26 March 2010. Retrieved from http://www. buero-echolot.de/.

Hendricks, P. J. J. \& Currier, C. 2005. Use of a Bridge for Day Roosting by the Hoary Bat, Lasiurus cinereus. The Canadian FieldNaturalist 19:132-133.

Herberstein, M. E., Wignall, A. E., Nessler,S. H., Harmer, A. M. T. \& Schneider, J. M. 2012. How effective and persistent are fragmentsof male genitalia as mating plugs? Behavioral Ecology 23:1140-1145. Retrieved January 20, 2013, from http://www.beheco. oxfordjournals.org/cgi/doi/10.1093/beheco/ ars088. DOI: https://dx.doi.org/10.1093/ beheco/ars088

Hutson, A. M., Mickleburgh, S. P. \& Racey, P. A. 2001. Microchiropteran Bats: global status survey and conservation action plan. Page 258 (A. M. Hutson, S. P. Mickleburgh, and P. A. Racey, Eds.). IUCN, Switzerland and Cambridge.

IbaÑEZ, C., \& PÉREZ-JoRdÁ, J. L. 1998. Longevity in the European free-tailed bat (Tadarida teniotis). Journal of Zoology (London) 245:213-214. DOI: https://dx.doi. org/10.1017/S0952836998236090 
IUCN. 2012. The IUCN Red List of Threatened Species. Version 2012.2. Retrieved January 18, 2013, from http://www.iucnredlist.org/.

Keeley, A. T. H. \& Keeley, B. W. 2004. The Mating System of Tadarida brasiliensis (Chiroptera: Molossidae) in a Large Highway Bridge Colony. Journal of Mammalogy 85:113-119. Retrieved January 20, 2013. DOI: http:// dx.doi.org/10.1644/BME-004

Keeley, B. W. 2007. Bats and Bridges. An Evaluation of Selected Bridges in Laois and Offaly. Laois County County and Offaly County Council.

Keeley, B. W., \& Tuttle, M. D. 1999. Bats in American Bridges. Transportation. Bat Conservation International, Inc., Austin, Texas, USA. Retrieved from www.batcon. org.

Laviolle, L., Bareille, S. \& Boleat, C. 2011. Mémo Technique: Les chauves-souris \& les ponts. Conservatoire Regional des Espaces Naturels de Midi Pyrénées. Retrieved from http://www.midi-pyrenees.developpementdurable.gouv.fr/.

Lemaire, M., \& Arthur, L. 2002. Les chauvessouris hôtes des ponts. Booklet. Direction Régionale de L'Environnement Centre. Retrieved from http://www.sfepm.org/.

Marnell, F., \& Presetnik, P. 2010. Protection of overground roosts for bats. Page 57. Eurobats, Bonn.

Marques, J. T., Rainho, A., Carapuço, M., Oliveira, P. \& Palmeirim, J. M. 2004. Foraging behaviour and habitat use by the European free-tailed bat Tadarida teniotis. Acta Chiropterologica 6:99-110. Museum and Institute of Zoology. DOI: http://dx.doi. org/10.3161/001.006.0108

Masterson, M., Buckley, D., O'Brien, M. \& KelleHer, C. 2008. An Investigation into Bridge Usage by Bats within the Sullane \& Laney River Catchments, Co. Cork. The Heritage Council \& National Parks and Wildlife Service. Co. Cork.

Mcdonnell, J. M. 2001. Use of Bridges as Day Roosts by Bats in the North Carolina Coastal Plain. North Carolina State University, Raleigh, North Carolina, USA.
Mitchell-Jones, A. J., \& McLeish, A. P. 2004. Bat workers' manual. Page 178 (A. J. MitchellJones and A. P. McLeish, Eds.), 3rd edition. Joint Nature Conservation Committee.

Mitchell-Jones, T., Bihari, Z., Masing, M. \& Rodrigues, L. 2007. Protecting and managing underground sites for bats. Page 38 Database. Eurobats, Bonn.

Munroe, K. E., \& Koprowski, J. L. 2012. Copulatory Plugs of Round-Tailed Ground Squirrels (Xerospermophilus tereticaudus). The Southwestern Naturalist 57:208-210. Retrieved January 20, 2013, from http:// www.bioone.org/doi/abs/10.1894/00384909-57.2.208. DOI: $\quad$ http://dx.doi. org/10.1894/0038-4909-57.2.208

NCHRP 25-25(04). 2005. Chapter 7: Bridge Maintenance. Final Report Environmental Stewardship Practices, Procedures, and Policies for Highway Construction and Maintenance v1.0. American Association of State Highway and Transportation Officials.

Palomo, J. L., Gisbert, J. \& Blanco, J. 2007. Atlas y Libro Rojo de los Mamíferos Terrestres de España. Page 588. Dirección General para la Biodiversidad-SECEM-SECEMU, Madrid.

Phillips, W., \& Inwards, S. 1985. The Annual Activity and Breeding Cycles of Gould's Long-Eared Bat, Nyctophilus gouldi (Microchiroptera: Vespertiionidae). Australian Journal of Zoology 33:111. Retrieved January 20, 2013. DOI: https:// dx.doi.org/10.1071/ZO9850111

Pysarczuk, S. \& Reiter, G. 2008. Bats and bridges in Austria. XIth European Bat Research Symposium. Cluj-Napoca.

Rainho, A., Rodrigues, L., Bicho, S., Franco, C. \& Palmeirim, J. 1998. Morcegos das Áreas Protegidas Portuguesas (I). Estudos de Biologia e Conservação da Natureza n²6. Instituto de Conservação da Natureza.

Reis, S. \& Rufino, R. 2012. Bats adapting to Human-made structures - The case of the "Concessão Transmontana". 32nd Annual Meeting of the International Association for Impact Assessment. IAIA12.

Rivers, N. M., Butlin, R. K. \& Altringham, J. D. 2006. Autumn swarming behaviour 
of Natterer's bats in the UK: Population size, catchment area and dispersal. Biological Conservation 127:215-226. Elsevier. DOI: https://dx.doi.org/10.1016/j. biocon.2005.08.010

Rodrigues, L., Zahn, A., Rainho, A. \& Palmeirim, J. M. 2003. Contrasting the roosting behaviour and phenology of a insectivorous bat (Myotis myotis) in its southern and northern distribution ranges. Mammalia 67:321-335. DOI: https:// dx.doi.org/10.1515/mamm.2003.67.3.321

Rolandez, J., \& Pont, B. 1986. Occupation des ponts par les chiroptères: premiers résultats de prospection. Bièvre 8:17-24.

Russo, D., Cistrone, L. \& Jones, G. 2007. Emergence time in forest bats: the influence of canopy closure. Acta Oecologica 31:119-126. Elsevier. DOI: https://dx.doi.org/10.1016/j. actao.2006.11.00.1

Russo, D., Jones, G. \& Migliozzi, A. 2002. Habitat selection by the Mediterranean horseshoe bat, Rhinolophus euryale (Chiroptera: Rhinolophidae) in a rural area of southern Italy and implications for conservation. Biological Conservation 107:71-81. Elsevier. DOI: $\quad$ https://dx.doi.org/10.1016/S006$\underline{3207(02) 00047-2}$
SHIEL, C. 1999. Bridge Usage By Bats In County Leitrim And County Sligo. The Heritage Council, Ireland.

Speakman, J. R., Bullock, D. J., Eales, L. \& Racey, P. A. . 1992. A problem defining temporal pattern in animal behaviour: clustering in the emergence behaviour of bats from maternity roosts. Animal Behaviour 43. DOI: https:// dx.doi.org/10.1016/S0003-3472(05)801707$\underline{1}$

Webb, P., Speakman, J. R. \& Racey, P. A. 1995. Evaporative water loss in two sympatric species of vespertilionid bat, Plecotus auritus and Myotis daubentoni: relation to foraging mode and implications for roost site selection. Journal of Zoology (London) 235:269-278. DOI: https://dx.doi. org/10.1111/j.1469-7998.1995.tb05143.x 